\title{
Evaluation of the environmental and economic impacts of electric propulsion systems onboard ships: case study passenger vessel
}

\author{
Nader R. Ammar ${ }^{1,2} \cdot$ Ibrahim S. Seddiek ${ }^{3}$ \\ Received: 10 November 2020 / Accepted: 1 March 2021 / Published online: 15 March 2021 \\ (C) The Author(s), under exclusive licence to Springer-Verlag GmbH Germany, part of Springer Nature 2021
}

\begin{abstract}
The International Maritime Organization (IMO) announced that maritime transport share by $2.89 \%$ in global greenhouse gases. Electric propulsion system appears as a promising option for reducing ship emissions, especially for high-powered vessels. The aim of the current paper is to investigate the environmental and economic impact of using electric propulsion systems. Simple eco-environmental model was presented to assess the best propulsion system for passenger ships. A comparison between diesel electric (DE) and combined gas turbine electric and steam (COGES) propulsion systems is conducted. As a case study, one of the cruise ships is selected. The results showed specific environmental benefits of COGES over DE propulsion option. From the design and operational viewpoints, COGES propulsion system is more energy efficient than DE by $9.3 \%$ and $27.55 \%$, respectively. Economically, the values of the life cycle costs are 5,013 and 6,042 \$/kW for DE and COGES systems, respectively. Finally, COGES seems as a greener option with a life-cycle cost-effectiveness of 612,1970 , and $6 \$$ ton for $\mathrm{NO}_{\mathrm{x}}, \mathrm{SO}_{\mathrm{x}}$, and $\mathrm{CO}_{2}$ emissions, respectively.
\end{abstract}

Keywords Passenger ships - IMO regulations - Diesel electric propulsion - COGES propulsion - Ship emissions · Cost-effectiveness analysis

\section{Introduction}

The maritime industry faces many challenges, whether at the level of legislation set by the International Maritime Organization (IMO) (Ammar and Seddiek 2020a; Lee 2019) or the economic crises that appear from time to time as that arising now from the Covid-19 virus (Doumbia-Henry 2020;

Responsible Editor: Philippe Garrigues

Nader R. Ammar

nammar@kau.edu.sa

Ibrahim S. Seddiek

prof.isibrahim@gmail.com

1 Department of Marine Engineering, Faculty of Maritime Studies, King Abdulaziz University, Jeddah 21589, Saudi Arabia

2 Department of Naval Architecture and Marine Engineering, Faculty of Engineering, Alexandria University, Alexandria 21544, Egypt

3 Department of Marine Engineering Technology, College of Maritime Transport \& Technology, Arab Academy for Science, Technology \& Maritime Transport, Alexandria 1029, Egypt
Michail and Melas 2020). Recent statistics show that ships are responsible for emitting 932 million tons of global $\mathrm{CO}_{2}$ emissions, which account for $2.6 \%$ of the total annual global emissions (Olmer et al. 2017; Seddiek 2016). Moreover, IMO (2020) reported that the share of shipping emissions in international anthropogenic emissions has increased from $2.76 \%$ in 2012 to $2.89 \%$ in 2018. Consequently, IMO has issued some legislations to reduce the adverse environmental impact (Halff et al. 2019; Ammar and Seddiek 2018). Mohseni et al. (2019) pointed that the highest percentage of ship emission mainly comes from propulsion systems. In most traditional ships, the emitted exhaust gases result from two main elements: auxiliary engines with low consumed power, such as diesel generators; and propulsion system, which are called main engines with high consumed power. Therefore, the highest percentage of ship emission is mainly coming from the ship propulsion systems.

In order to meet IMO emission regulations and achieve efficient ship operations, researches are focusing on substituting conventional propulsion drives with more efficient systems (Geertsma et al. 2017; Curley 2012). Electric propulsion system is one of the alternative drives for mechanical ones adapted to different ship types providing more efficient 
operation at low speed (Nuchturee et al. 2020; Lim et al. 2019). Many researchers studied the effect of applying electric propulsion to commercial, cruise, and naval vessels (Hong et al. 2012; Koo 2009). Kim (2007) and Koo (2009) showed that electric propulsion system can be considered an efficient system with low nitrogen oxides emissions to comply with the new greenhouse gas emission regulations from ships. Kim (2013), Bassam et al. (2016), and MAN (2018) displayed that Azipod propulsion can be used with electric propulsion system for some ships, like offshore support vessels, LNG carriers, cruise, and passenger ships and ferries, which improves their maneuverability. Prempraneerach et al. (2009) studied the prediction of power consumption and modeling of the dynamic characteristics of ship electric propulsion system. Zahedi and Norum (2013) and Kwak (2014) presented a simulation for the electric system components and validating the design and mathematical models. Kwak (2014) and Lim et al. (2019) analyzed a modeling of the ship electric propulsion based on the shipping and load flow characteristics. Furthermore, Dedes et al. (2012) and Bassam et al. (2017) discussed the applicability of using electric concept as a part of hybrid propulsion system for a certain ship type. From the previous literature, electric propulsion system is considered a rich concerning research point due to its environmental and economic effects. Statistics reveal that the number of electric propulsion vessels in global ship contracts has increased over the years from 2000 to 2017 as shown in Fig. 1, most of which are installed onboard passenger ships (Clarksons Research 2020; Jeon and Kim 2020). As a specific ship type, UNCTAD (2019) showed that passenger ships present $4 \%$ of the total world ship number with $3 \%$ of the world gross tonnage. Statistics reveal that although the dead weight of passenger ships sailing worldwide account for only $0.35 \%$ of the total world ships' dead weight, they share by $11.4 \%$ of total ships' value in dollars.

The aim of the present work is to highlight the necessity of shifting from conventionally powered passenger ships to alternative propulsion systems with an emphasis on electric ones. The objectives are giving a brief description regarding the systems' technicality, in addition to reaching the best ships' characteristics with respect to the environment and economic issues. The present paper discusses the technical, environmental, and economic issues in case of applying an electric propulsion system for passenger ships. Diesel electric (DE) and combined gas turbine electric and steam (COGES) are selected to evaluate the corresponding environmental and economic benefits. Based on previous work (Benvenuto et al. 2011; Haglind 2008), it is difficult to present reliable cost figures of marine combined gas and steam power plant. One of the main scopes of the current paper is to find a detailed cost of the combined cycle. As a case study, one of passenger ships with a sailing route between Vancouver and Tokyo ports is examined.

\section{Description of alternative electric propulsion systems for passenger vessels}

One of the clean cost-effective propulsion options for passenger vessels is the electric propulsion system. Its opportunity to replace the conventional propulsion systems is increased, especially with the new IMO regulations for reducing exhaust gas emissions and improving the operational energy efficiency of ships. There are three available electric propulsion options for passenger vessels: diesel electric (DE), combined gas turbine electric and steam (COGES), and hybrid propulsion systems. The first option is the diesel electric propulsion option operated either by fixed pitch, or by controllable or Azipod propellers (Peng et al. 2020; Nuchturee et al. 2020). Figure 2 shows an example for the diesel electric propulsion system illustrating the different components. In diesel electric propulsion system, the electric motors are used to drive the ship propellers with high efficiency at different ranges of loads. Three to eight sets of diesel generators with synchronous generators can be used in this system. The main busbar is supplied by electric power from the generators. It is divided into different sections to guarantee redundancy. High voltage (HV) levels $(11 \mathrm{kV})$ are normally used in electric propulsion systems especially for high output power (more than $20 \mathrm{MW}$ ). The HV systems are used mainly for ship propulsion and thrusters using synchronous or asynchronous motors. Synchronous motors are used for high power rating while asynchronous drives are used for thrusters. The auxiliaries and hotel loads are operated using low-voltage distribution network (MAN 2018; Jeong et al. 2018).

The second electric propulsion option is the combined gas turbine electric and steam (COGES). In COGES plant, the steam turbine is powered by steam produced from the gas turbine lost heat as shown in Fig. 3. In this plant, the recovered heat energy reduces the specific fuel consumption of the combined cycle. The produced exhaust gases from gas turbine (1) are used in waste heat recovery boiler (3). The produced steam from the steam turbine (2) is used for driving the steam turbine and for vessel heating applications (12). The main busbar is supplied by electric power from both gas $(1,4)$ and steam $(2,4)$ turbo generators. This electric power is used to operate the electric motor (5) which drives the ship propeller (7) and vessel electric network (11). COGES system differs from further combined marine power plants that it is not designed to operate on gas or steam turbine alone. For example, combined steam and gas (COSAG) system uses steam turbine for running ship propeller during cruise, and gas turbine complements it at high speeds (Benvenuto et al. 2012; Ibrahim et al. 2011). One of the main advantages of this system over conventional propulsion system is that at low gas turbine loads, the steam turbine recovers the lost heat, and this leads to constant fuel consumption over a wide range of operational loads. In addition, the exhaust gas boiler 
Fig. 1 Electric propulsion share in total ship contracts (left) and forecast of electric ship markets (right)

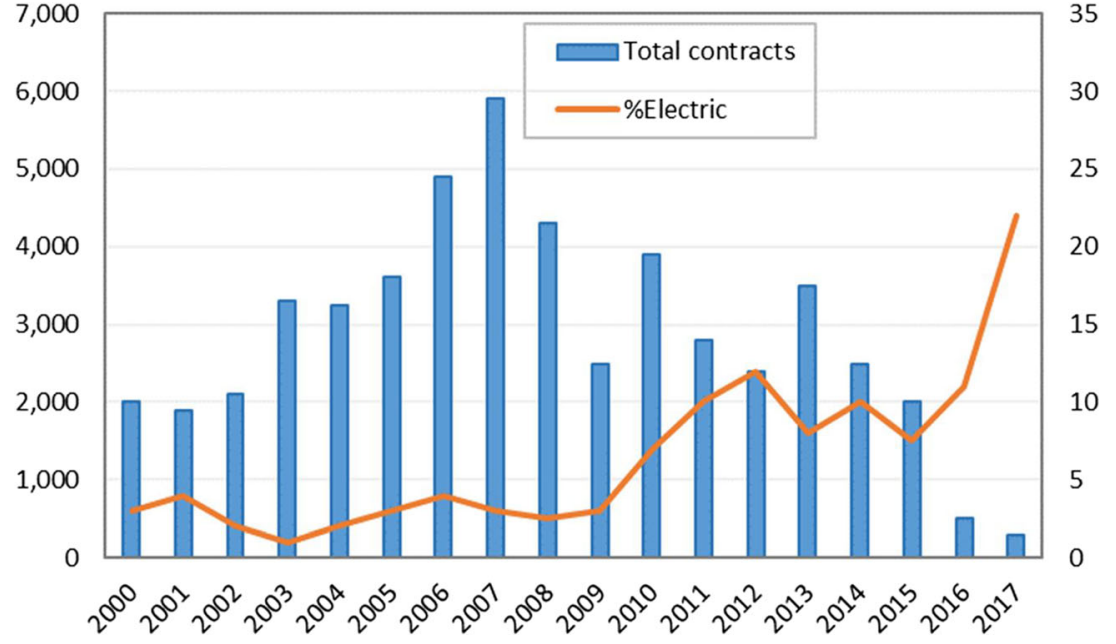

eliminates the need for auxiliary boiler. This will consequently decrease the exhaust gas pollutants from the propulsion system (Mrzljak and Mrakovčić 2016; Haglind 2008). Gas turbine with mechanical drive is favored for fast ferries to satisfy the required weight and space restrictions. On the other hand, the COGES power plant is preferred for cruise ship to cope with the part load operations and large steam quantities required for the auxiliary systems (Haglind 2008; Rivera-Alvarez et al. 2015). Recently, the main restrictions for using GOGES propulsion systems onboard ships are related to economic issues.

The third propulsion option is the hybrid propulsion system. It is a combination of the conventional and electric propulsion systems (Xiao et al. 2020; Capasso et al. 2019). This type is considered effective when the electrical load required from generators can be provided from the propulsion system as shown in Fig. 4. The figure shows that the hybrid propulsion system may appear in two options. The first one is mechanical hybrid system. In this configuration, the propulsion depends mainly on the energy derived from the main engine, which is a two-stroke diesel engine, while the electric generators are relied upon to obtain the electrical load required for the ship (Jaurola et al. 2019; Geertsma et al. 2017). In case of high-speed mode, the power needed for propulsion is obtained mechanically. However, in the case of low speeds, this can be obtained through electric generators. The second option shows the possibility of providing the energy required for propulsion through a group of batteries that give a high
Fig. 2 Diesel electric propulsion system (1, diesel engine; 2 , electric generator; 4 , busbar; 5 , bow thruster motor; 6 , step down transformer; 7, power convertor; 8 , propulsion motor; 9 , propeller; 10 , auxiliary loads)

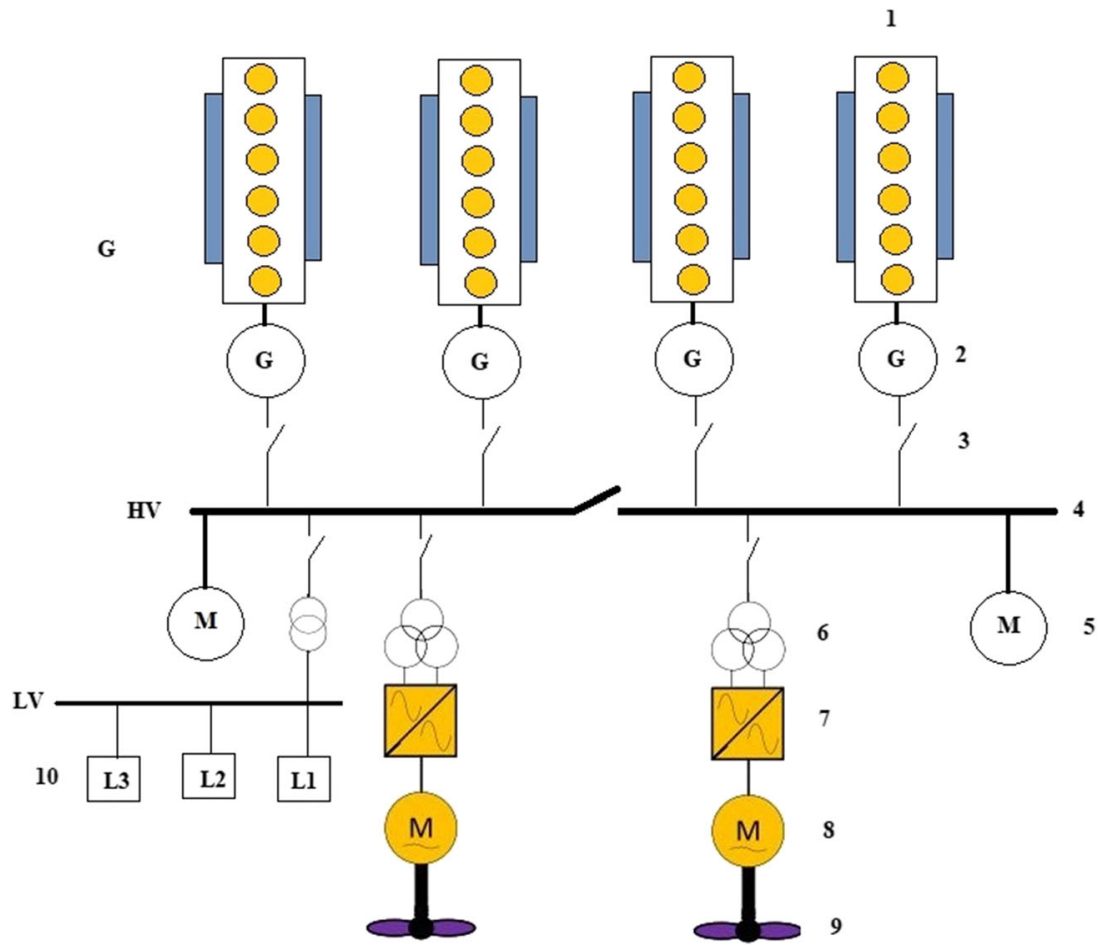


Fig. 3 COGES electric propulsion system

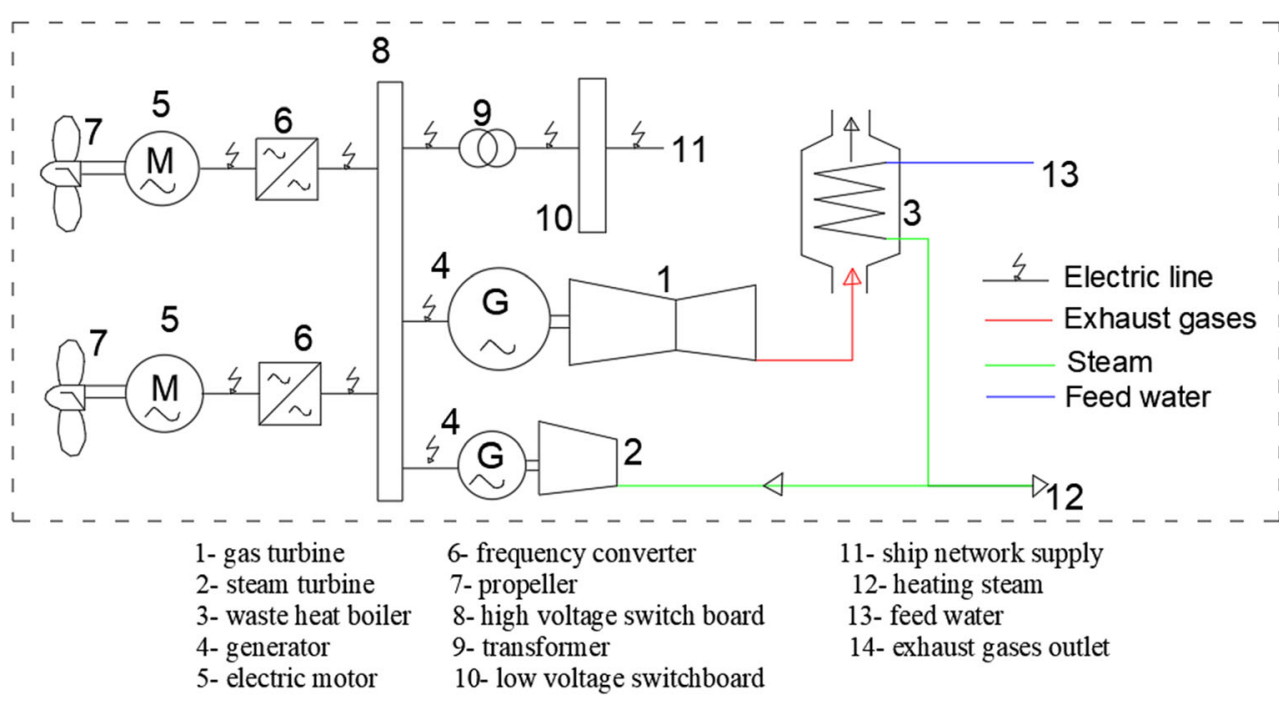

capacity of direct current (DC), and then this energy could be reserved in energy storage (ES) before converted into alternator current (AC) through a DC-AC inverter (Magdalena and Wojciech 2019; Lee et al. 2014).

Besides the abovementioned options, there are several electric propulsion systems that are worthwhile to mention such as dual fuel diesel electric and hydrogen fuel cell-based propulsion. Dual fuel engines use natural gas as an alternative fuel with environmental and economic advantages (Su et al. 2020; Ammar 2019). Hydrogen fuel cell is an electrochemical device that converts hydrogen energy directly into electricity with negligible exhaust gas emissions (Welaya et al. 2014; Ouyang et al. 2020). Due to the difficulty of natural gas bunkering, which is needed for dual fuel engines, and the high initial and operating costs of fuel cell, these options face challenges to be applied for passenger ships.

\section{Methodology for performance evaluation}

This section includes the different related issues concerning applying electric propulsion systems onboard
Fig. 4 Options of hybrid electric propulsion system

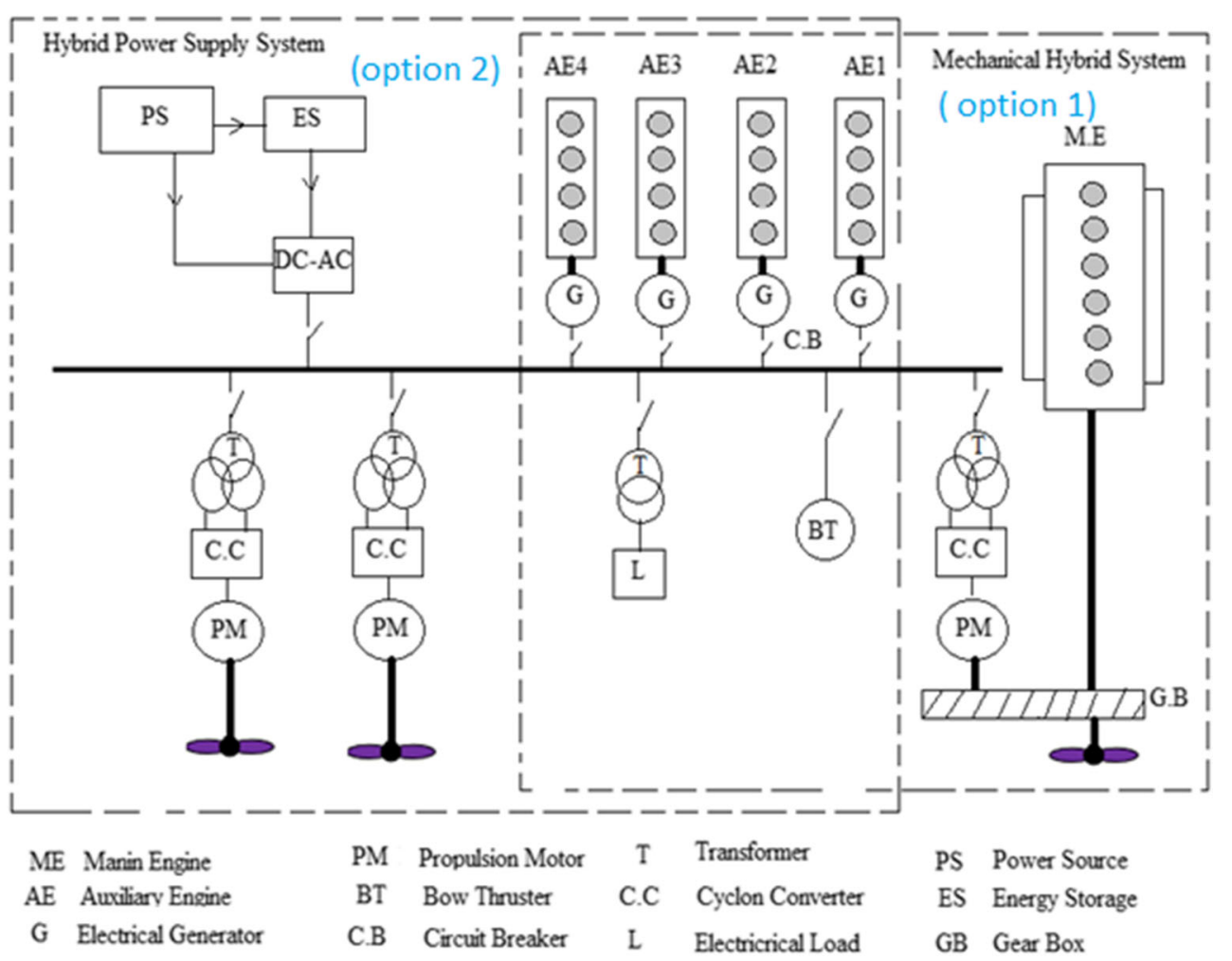


passenger ships. The first part displays the main equations that can be used to assess the environmental aspects of a certain electric propulsion options. The second part deals with the economic aspects of the DE and COGES propulsion systems. Furthermore, the section ends by the evaluation of the life cycle cost-effectiveness for the proposed electric propulsion options.

\section{Environmental modeling}

The total passenger ship emissions every trip $\left(m_{\text {tot }}\right)$ are the summation of ship emissions during cruise (Cr.), hoteling (Hot.), and maneuvering (Man.), as illustrated in Eq. (1).

$\mathrm{m}_{\text {tot }}=\mathrm{m}_{\text {Hot. }}+\mathrm{m}_{\text {Man. }}+\mathrm{m}_{\mathrm{Cr}}$.

Passenger ship emissions per trip ( $\left.m_{\text {trip }}\right)$ can be estimated depending on the main and auxiliary engine powers as shown in Eq. (2).

$\mathrm{M}_{\text {trip }, \mathrm{n}, \mathrm{m}, \mathrm{ft}}=\sum_{\text {mod. }}\left[\mathrm{H}_{\text {mod. }} \sum_{\mathrm{C}}\left(\mathrm{OP}_{\mathrm{C}} \times \mathrm{LP}_{\mathrm{C}} \times \mathrm{F}_{\mathrm{C}, \mathrm{n}, \mathrm{m}, \mathrm{ft} \text {,mod. }}\right)\right]$

where mod. refers to the cruise, maneuvering, and hoteling modes of each trip; $C$ is the selected engine category; OP and LP are the output power of the selected engine $(\mathrm{kW})$ and its load percent, respectively; $H$ is the working hours during each mode of the ship; $n$ is the category of exhaust gases, $m$ is the type of the used engine diesel engine, gas turbine...etc.; $\mathrm{ft}$ is the used fuel; and $F$ is the fuel emission factor in grams/kilowatt hour. The emission factors for $\mathrm{NO}_{\mathrm{x}}$, $\mathrm{SO}_{\mathrm{x}}$, and $\mathrm{CO}_{2}$ are $13,0.4$, and $620.62 \mathrm{~g} / \mathrm{kWh}$, respectively, for medium speed marine diesel engine operated with ultra-low sulfur heavy fuel oil (ULSHFO $0.1 \%$ S). These factors are 14, 0.0 , and $590 \mathrm{~g} / \mathrm{kWh}$, respectively, for COGES propulsion system powered by marine diesel oil (MDO $0.1 \%$ S) (Ammar and Seddiek 2020a; Ammar 2019).

In addition, the reference values for $\mathrm{CO}_{2}$ emissions can be calculated using the reference energy efficiency design index

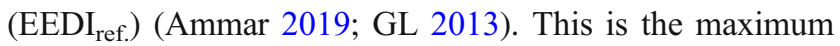
allowed value for the calculated energy efficiency design index $\left(E E D I_{\text {cal. }}\right)$ set by IMO for a specific ship type (IACS 2016). EEDI $I_{\text {ref. }}$ can be evaluated using Eq. (3).

$$
\mathrm{EEDI}_{\mathrm{ref} .}=\left(\frac{170.84}{\mathrm{GT}^{0.214}}\right)\left(1-\frac{X}{100}\right)
$$

where GT is the passenger ship gross tonnage; $X$ is the reduction percentage set by IMO, $5 \%$ in $2015,20 \%$ in 2020 , and $30 \%$ in 2025 (ABS 2013; Ammar and Seddiek 2020b).

The EEDI $\mathrm{Cal}_{\text {cal }}$ in $\mathrm{gCO}_{2} / \mathrm{GT}$-NM for a passenger vessel, operated with electric propulsion, can be calculated using Eq. (4) (IMO 2014; IACS 2016).
$\mathrm{EEDI}_{\text {cal. }}=\frac{\left(\frac{\mathrm{HL}_{\text {max. }}}{\eta_{\text {gen. }}}+\frac{\sum_{i=1}^{\mathrm{n}}(0.75 . \mathrm{MPP}(i))}{\eta_{\mathrm{PTI}} \cdot \eta_{\text {gen. }}}\right) \cdot\left(C_{\mathrm{F}} \cdot \mathrm{SFC}_{\mathrm{AE}}\right)}{\mathrm{GT} \cdot v_{\text {ref. }}}$

where $\mathrm{HL}_{\max }$ is the auxiliary electric power consumption during ship cruise in $\mathrm{kW} ; \eta_{\operatorname{gen}}$ is the average efficiency of the diesel generators, which can be assumed in the range of 95 to 98\%; MPP is the rated output power in $\mathrm{kW}$ of an electric propulsion motor $(i)$; $\eta_{\mathrm{PTI}}$ is the electric propulsion systems' efficiencies including transformer, converter, and propulsion motor at $75 \%$ of the electric motor output rated power; $C_{\mathrm{F}}$ is the fuel conversion factors of the consumed fuel to $\mathrm{CO}_{2}$, $\mathrm{SFC}_{\mathrm{AE}}$ is the average specific fuel consumption for all engines at $75 \%$ of the MCR power in $\mathrm{g} / \mathrm{kWh} ; V_{\text {ref }}$ is the operational vessel speed in knots.

Finally, the energy efficiency operational indicator (EEOI) can be estimated in ton $\mathrm{CO}_{2} / \mathrm{GT}$.NM as illustrated in Eq. (5) (Acomi and Acomi 2014; Nuchturee et al. 2020).

$\mathrm{EEOI}_{\text {average }}=\frac{\sum_{\mathrm{i}} \sum_{\mathrm{j}} \mathrm{FC}_{\mathrm{ij}} \cdot \mathrm{C}_{\mathrm{F}(\mathrm{j})}}{\sum_{\mathrm{i}} \mathrm{GT}_{\mathrm{i}} \cdot \mathrm{D}_{\mathrm{i}}}$

where $i$ and $j$ are the vessel trip number and the fuel used during ship cruise, respectively; FC is the amount of fuel consumption each trip. GT is the gross tonnage for passenger ships; $D$ is the traveled distance in nautical miles.

\section{Economic modeling}

To evaluate certain propulsion systems from the economic point of view, both the life cycle cost (LCC) and the corresponding gains should be calculated. The value of life cycle cost could be estimated as follows (European commission 2014):

$$
\begin{aligned}
\text { LCC }_{P S}= & \sum_{\mathrm{i}=1}^{\mathrm{n}} \text { CAPEX } \\
& +\sum_{\mathrm{t}=0}^{\mathrm{L}} \frac{\text { OPEX }_{\mathrm{t}}+\text { RISKEX }_{\mathrm{t}}}{(1+\mathrm{r})^{\mathrm{t}}}-\text { D\&D }_{\mathrm{p}}
\end{aligned}
$$

where CAPEX is the capital expenditures, OPEX is the operating expenditures, RISKEX is the risk expenditures, $r$ is the discount rate in percent, $L$ is the expected time span in years, and $t$ is the working years range from 0 to $\mathrm{L}$, respectively (Banawan et al. 2010). $n$ is the propulsion system, and $\mathrm{D} \& \mathrm{D}_{\mathrm{p}}$ is decommissioning and disposal price.

The value of the capital expenditures depends mainly on the power consumed by the prime mover and auxiliary machinery, and could be calculated as follows (Sadek and Elgohary 2020):

$\mathrm{CAPEX}=\mathrm{P}_{\mathrm{i}} \cdot \mathrm{U}_{\mathrm{Ci}} \cdot\left(1+\mathrm{ins}_{\mathrm{p}}\right)$ 
where $P_{i}$ is the power of each system's component in $\mathrm{kW}, U_{\mathrm{Ci}}$ is the system power's unit cost in $\$ / \mathrm{kW}$, and ins is the percent of installation cost. However, the value of operating expenditures is divided into five main elements as shown in Eq. (8).

$\mathrm{OPEX}=C_{\mathrm{M}}+C_{\mathrm{Crew}}+C_{\mathrm{P}}+C_{\text {Tech. }}+C_{\mathrm{CO} 2}$

where $C_{\mathrm{M}}$ is the maintenance cost, $C_{\text {crew }}$ is the labor cost, $C_{\mathrm{p}}$ is the fuel costs, $C_{\text {Tech. }}$ is any other technical costs such as classification societies and insurance, and is the carbon tax cost. The fuel cost sharing by a high percentage of the total operating cost and could be determined as follows (Ammar and Seddiek 2017; Elgohary et al. 2014):

$C_{\mathrm{p}}=\sum_{\mathrm{AE}=1}^{i} \quad \sum_{m=1}^{3} L_{\mathrm{F}, \mathrm{m}} \cdot T_{\mathrm{p}, \mathrm{m}} . \quad F_{\mathrm{C}, \mathrm{m}} \cdot C_{\mathrm{f}}$

where $L_{\mathrm{F}}$ is the engine load factor, $T_{\mathrm{p}}$ is the operation time of the propulsion system expressed in hours/year, $F_{\mathrm{C}}$ is the fuel consumption in ton/hour, $C_{\mathrm{f}}$ is the specific fuel price in US\$/ton, and $k$ is the number of working diesel electric generators $(\mathrm{m})$ in ship mode: $1=$ standby, $2=$ maneuvering, and $3=$ cruising. $F_{\mathrm{C}, \mathrm{m}}$ is the fuel consumption. It can be presented as a function of specific fuel consumption and the rated power. Maintenance and repair costs can be estimated as a percent of the construction costs of the ship or a function of power-time rate (Ammar and Seddiek 2020a).

With reference to crew cost, for passenger ships, it could be calculated as a function of ship gross tonnage (GT), as follows (Ros Chaos et al. 2020):

$$
\mathrm{C}_{\mathrm{W}}=111.85 \mathrm{GT}+\left(1 \times 10^{6}\right)
$$

The previous cost elements are considered internal costs; however, there is an external cost that appears in the form of carbon tax, which is related to GHG emission. The external costs of carbon emission were added to the LCCs to demonstrate to what extent they would affect the economic viability, and may be estimated as follows:

$C_{\mathrm{CO} 2}=\mathrm{m}_{\mathrm{CO} 2} \cdot \mathrm{R}_{\mathrm{Tax}} \cdot \mathrm{T}_{\mathrm{p}, \mathrm{m}}$

where $m_{\mathrm{CO} 2}$ is the carbon dioxide generated per round trip in ton/hour, and $R_{\text {Tax }}$ is the specific charge of carbon dioxide in US\$/ton.

The latest cost component is RISKEX in USD, which presents the cost that could be depleted, as follows (Ahn et al. 2017):

RISKEX $=\mathrm{R}_{\mathrm{PD}}+\mathrm{R}_{\mathrm{PR}}+\mathrm{R}_{\text {Padd. }}$

where $R_{\mathrm{PD}}$ is the fright damage cost due to propulsion failure, $R_{\mathrm{PR}}$ is the repair cost due to propulsion failure, and $R_{\text {Padd }}$ is any other non-determined cost due to propulsion failure.

The freight damage cost due to propulsion failures considers the non-reliability, shipping, and freight charge. This value depends mainly on the number of trips that will be canceled as a result of propulsion failures (Eq. (12A)).

$\mathrm{R}_{\mathrm{PD}}=(1-\beta) \times \mathrm{N}_{\text {passenger }} \times \mathrm{C}_{\text {freight }}$

where $\beta$ is the percent of propulsion system reliability, $N_{\text {passenger }}$ is the passengers that could not be transported due to canceled trips, and $C_{\text {freight }}$ is the freight charge of one passenger in USD.

The repair cost due to propulsion failure considers the nonreliability, criticality, man-hour, and labor cost for each failure component, as shown in Eq. (12B).

$\mathrm{R}_{\mathrm{PR}}=\sum_{\mathrm{k}=0}^{\mathrm{n}}(1-\beta) \times \mathrm{N}_{\text {Failures }} \times \mathrm{MP}_{\mathrm{RH}} * \mathrm{~L}_{\mathrm{c}}$

where $N_{\text {Failures }}$ is the number of propulsion system failures, $\mathrm{MP}_{\mathrm{RH}}$ is the man-hour for repairing the propulsion in hour, and $L_{\mathrm{c}}$ is the labor cost of repair in US $\$ / \mathrm{h}$. This value depends mainly on the nature of the specific failure $(\mathrm{k})$, such as generators, turbines, and pumps.

Finally, $R_{\text {Padd }}$ is any other non-determined cost due to propulsion failure, such as survey inspection regarding the failure items, port facilities cost, and spar part cost.

Finally, to reach an environmental propulsion system, the value of cost-effectiveness $\left(C_{\mathrm{E}}\right)$ in ( $\$$ /ton) should be estimated (Mohseni et al. 2019), where $\Delta_{\text {Emissions, }}$ in ton, is the reduction of exhaust gas emissions when a certain propulsion system is applied.

$\mathrm{C}_{\mathrm{E}}=\frac{\text { Profit }_{\text {loss }}}{\Delta_{\text {Emissions }}}$

where the term profit $t_{\text {loss }}$ refers to the annual ship's economy loss due to applying a certain propulsion option that targets an environment benefit. This loss may appear as a result of using expensive marine fuel, cost of specified equipment, or other costs.

\section{Passenger vessel case study}

A new sister ship for the Holland America line passenger vessels is designed with a total gross tonnage of 82,897. The new ship sisters include MS Westerdam, MS Oosterdam, MS Zuiderdam, and MS Noordam with IMO numbers of 9226891, 9221281, 9221279, and 9230115, respectively (Marine Traffic 2020; CruiseMapper 2020). The main ship's particulars of the selected case study are displayed as shown in Table 1 . The total installed electric power for the ship is $51,840 \mathrm{~kW}$, which covers both the electric propulsion and auxiliary/hotel power requirements for the ship. The propulsion system is composed of two ABB Azipod propellers operated with two electric motors with an output power of $17,200 \mathrm{~kW}$ for each. The maximum hotel loads required are 4,000 $\mathrm{kW}$ during ship cruise. 
The selected propulsion system for the current case study is electric propulsion configuration that can be achieved from two options. The first option is diesel electric propulsion system and the second option is combined gas turbine and steam turbine system as shown in Fig. 5.

Diesel electric propulsion option is composed of six electric generators that provide the electricity to the propeller through step down transformer to reduce the voltage by the way that provides enough starting torque. Cyclone convertor (C.C) regulates the frequency according to the required propulsion motor speed (P.M). The total installed power that could be provided by generator sets is $51,840 \mathrm{~kW}$. On the other hand, the second option is composed of gas turbine and steam turbine. The steam turbine is working by the exhaust gases of gas turbine (Mrzljak and Mrakovčić 2016; Szymon 2018).

With reference to the ship's route, generally, most passenger ships seek to choose the best route through which they can attract the largest number of passengers, which will have a good effect on the ships' economies. The choice of route for a passenger ship is affected by some factors, including the ports to be visited and the distance the vessel sails. As a case study, the ship under study takes a sailing route from a port in Vancouver, Canada, to a port in Tokyo, Japan, as shown in Fig. 6.

The ship travels a distance of $10,560 \mathrm{~nm}$ for the 20 day trip (Holland America Line 2020); through this route, the vessel passes through several ports as it stays for a certain period at each port. The average number of trips per year is five. The main ports that the ship will call are Vancouver, Ketchikan, Sitka, Icy Strait, and Hubbard Glacier in Canada; Vaidez, Seward, and Kodiak, Dutch Harbor, in the USA; Petropavlovsk in Russia; and Sapporo and Tokyo in Japan. This route is considered for the famous passenger ship lines as it attracts millions of passengers yearly, not only from the mentioned countries but also from worldwide.

The passenger vessel is assumed to be operated by electric propulsion system using diesel electric (DE) or combined gas and steam (COGES) with a total power of $51,840 \mathrm{~kW}$. The total output power and average specific fuel consumption for the DE propulsion system are $51.84 \mathrm{MW}$ and $155.6 \mathrm{~g} / \mathrm{kWh}$ (Wartsila 2020). The nominal engine efficiency is of $41.3 \%$. The proposed COGES engine (LM2500 general electric) specific fuel consumption, net power, and efficiency are $155.6 \mathrm{~g} / \mathrm{kWh}, 43.9 \mathrm{MW}$, and

Table 1 The main ship's particulars of the selected case study

\begin{tabular}{ll}
\hline Owner & Holland America line \\
\hline Total gross tonnage & $82,897 \mathrm{gt}$ \\
Length, beam, draught & $285 \mathrm{~m}, 32 \mathrm{~m}, 7.8 \mathrm{~m}$ \\
Ship speed (service/maximum) & $22 / 24 \mathrm{knots}$ \\
Number of passengers & 2,366 \\
Number of crew & 820 \\
Total installed electric power & $51,840 \mathrm{~kW}$ \\
\hline
\end{tabular}

54.2\% (General Electric 2019). In order to cover electric power requirements in ship ports according to IMO regulations, COGES propulsion system is provided with two diesel generators with output power of $400 \mathrm{~kW}$, each with specific fuel consumption and nominal efficiency of $204 \mathrm{~g} / \mathrm{kWh}$ and $41.3 \%$ (CAT 2012). The proposed fuels for the diesel generators and COGES engines are ULSHFO (0.1S) and MDO $(0.1 \% \mathrm{~S})$, respectively, with engine load during cruise of $90 \%$. With reference to the economic issue, the crew cost will be the same as the number of crew will not be affected by the propulsion system (Ros Chaos et al. 2020). Accurate figures and values of the specific cost parameters mentioned in Eqs. (12A) and (12B) were difficult to collect through this study. But depending on the study carried out by Ahn et al. (2017), the risk values are assumed to be $1 \%$ and $1.5 \%$ of the life cycle cost for DE and COGES propulsion systems, respectively. These values could be supported by the following facts. Three main elements play a role in estimating the RISK costs of the current case study: the prime mover reliability, repair time, and power redundancy. Boiler and steam turbines have relatively high failure rates than diesel engines. COGES reliability is about 0.979 and for DE, which equals 0.999 . The repair time of any prime mover will vary according to the nature of failure. Finally, with reference to power redundancy, a diesel generator does not take any time to restart; however, a steam turbine takes not less than 2 h. All the previous factors will lead to increasing the RISK cost values for the COGES propulsion option.

\section{Results and discussions}

In this section, an environmental and economic assessment for (DE) and COGES electric propulsion options for the case study is presented, highlighting the most benefits and drawbacks of each option.

\section{Environmental comparison}

Three main types of air pollutants from ship prime movers are considered in IMO regulations. These exhaust gases are nitrogen oxides $\left(\mathrm{NO}_{\mathrm{x}}\right)$, sulfur oxides $\left(\mathrm{SO}_{\mathrm{x}}\right)$, and carbon dioxide $\left(\mathrm{CO}_{2}\right)$. Figure 7 shows the different exhaust gas emissions from DE and COGES propulsion options. $\mathrm{NO}_{\mathrm{x}}$ emissions are presented from the two options as a result of the presence of nitrogen content in both atmospheric air and sometimes in the fuel. These emissions are strongly affected by the combustion temperature inside the engine (Mrzljak and Mrakovčić 2016). Therefore, the diesel engines produce higher $\mathrm{NO}_{\mathrm{x}}$ rates than gas turbines as a result of their increased peak temperatures of combustion. In addition, the combustion of ULSHFO produces higher $\mathrm{NO}_{\mathrm{x}}$ rates than $\mathrm{MDO}(0.1 \% \mathrm{~S})$. On the other hand, the $\mathrm{SO}_{\mathrm{x}}$ emission is highly affected by the sulfur content of the used fuel. DE propulsion option operated by ULSHFO produces higher $\mathrm{SO}_{\mathrm{x}}$ emissions than COGES propulsion 
Fig. 5 Proposed options for electric propulsion arrangements for the case study

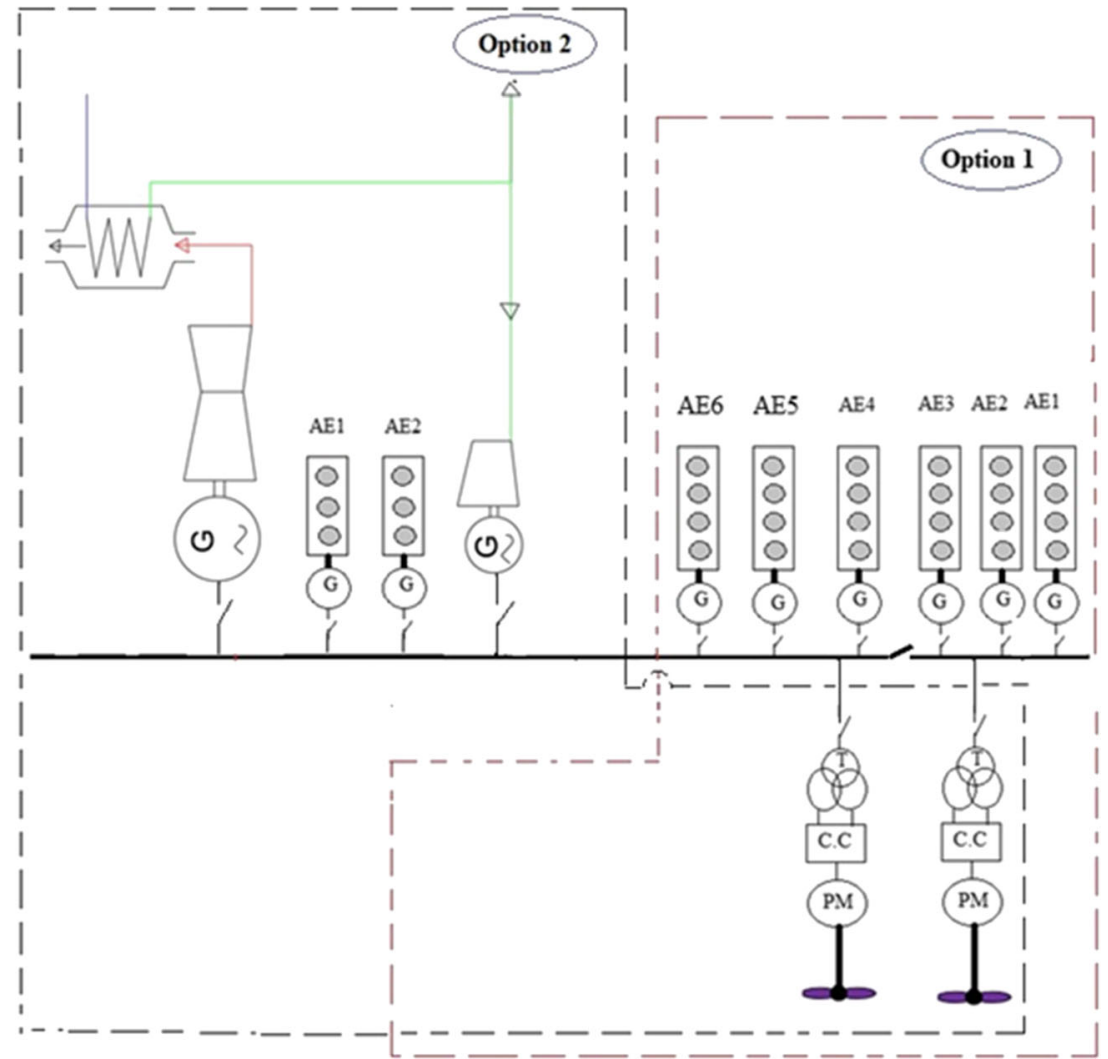

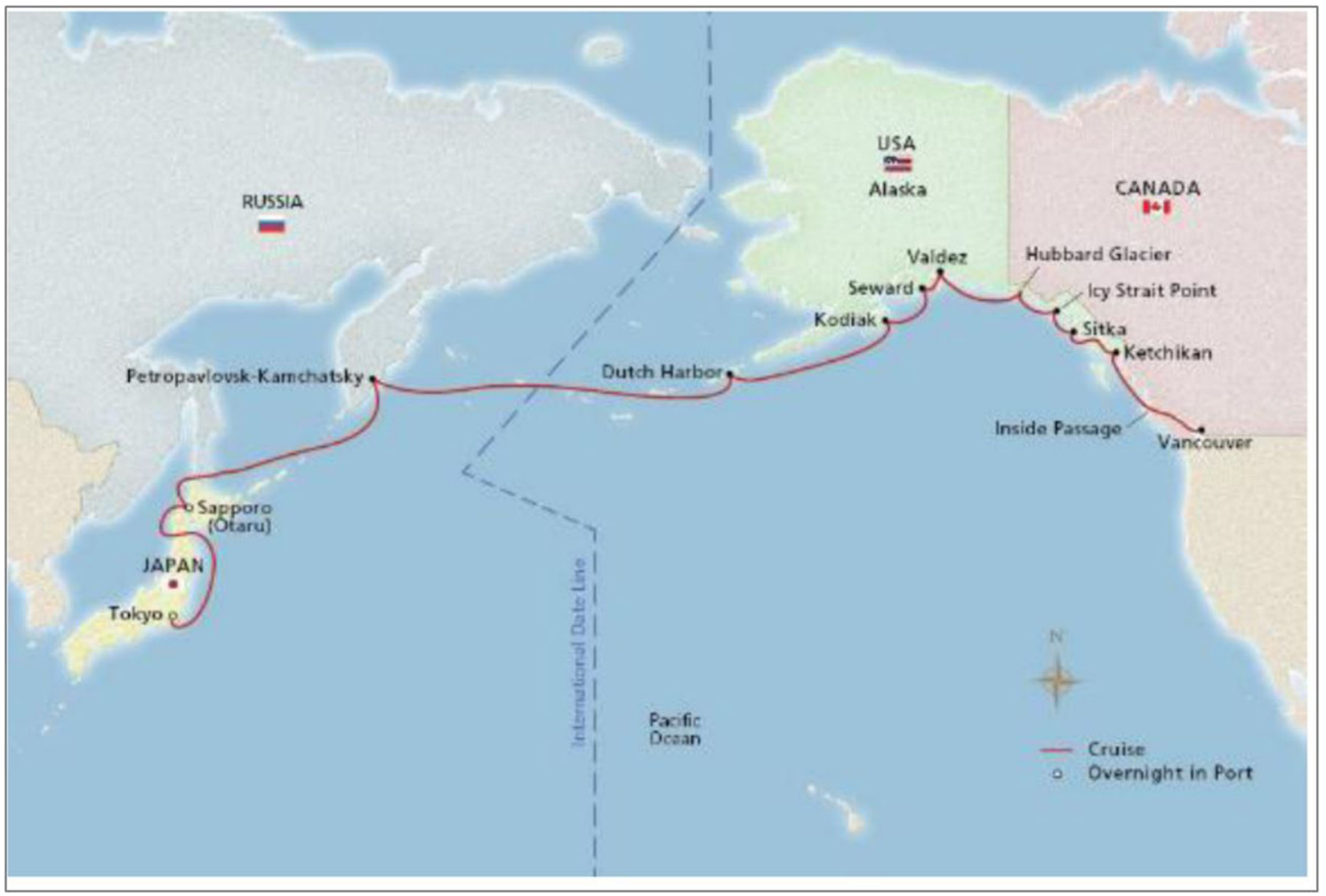

Fig. 6 Ship route for the case study 
Fig. 7 Air pollutants from the two propulsion options

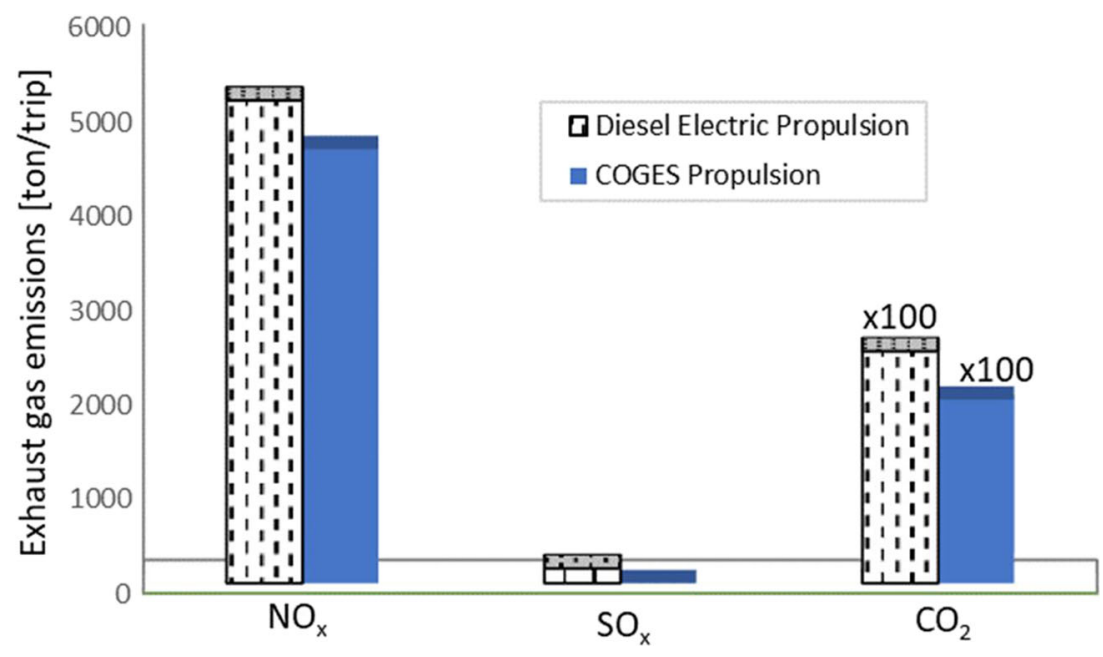

option operated by MDO $(0.1 \% \mathrm{~S})$. Finally, the production of $\mathrm{CO}_{2}$ emissions is affected by the engine efficiency and the hydrogen-carbon ratio in the combusted fuel. As the percent of carbon by mass of combustion ULSFO is more than the percent of carbon by mass of combustion MDO, DE propul-

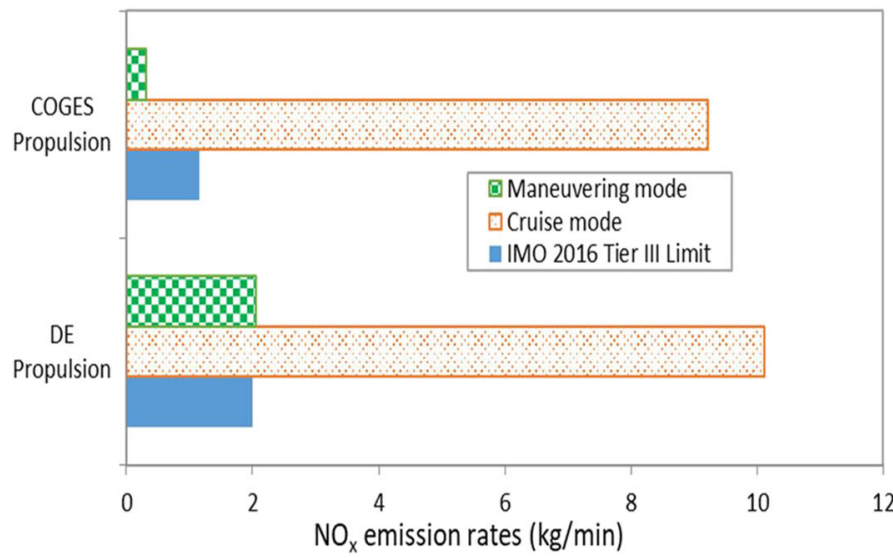

sion option will produce higher $\mathrm{CO}_{2}$ emissions than that of the COGES propulsion option.

The International Convention for the Prevention of Pollution from Ships (MARPOL) annex VI determines the acceptable $\mathrm{NO}_{\mathrm{x}}$ and $\mathrm{SO}_{\mathrm{x}}$ emission rates from marine engines.

Fig. $8 \mathrm{IMO} \mathrm{NO}_{\mathrm{x}}$ and $\mathrm{SO}_{\mathrm{x}}$ emissions for theDE and COGES propulsion options

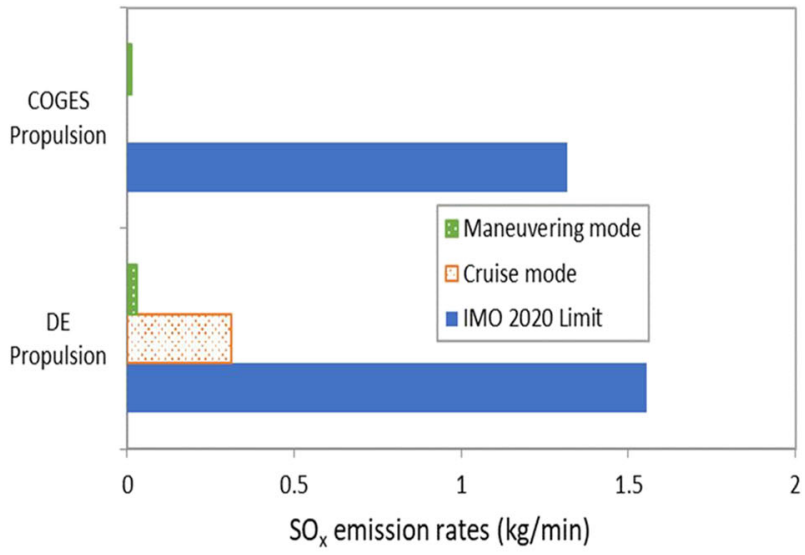

Fig. $9 \mathrm{NO}_{\mathrm{x}}$ emission reduction using SCR system compared with IMO limits

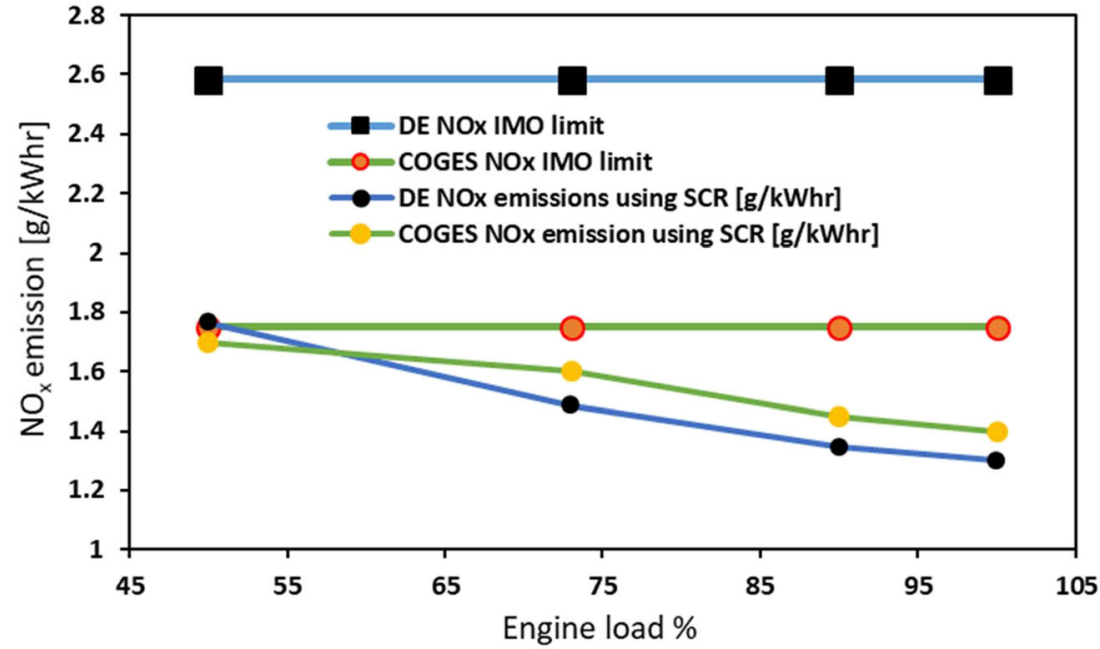


Fig. 10 Reference EEDI values for the case study
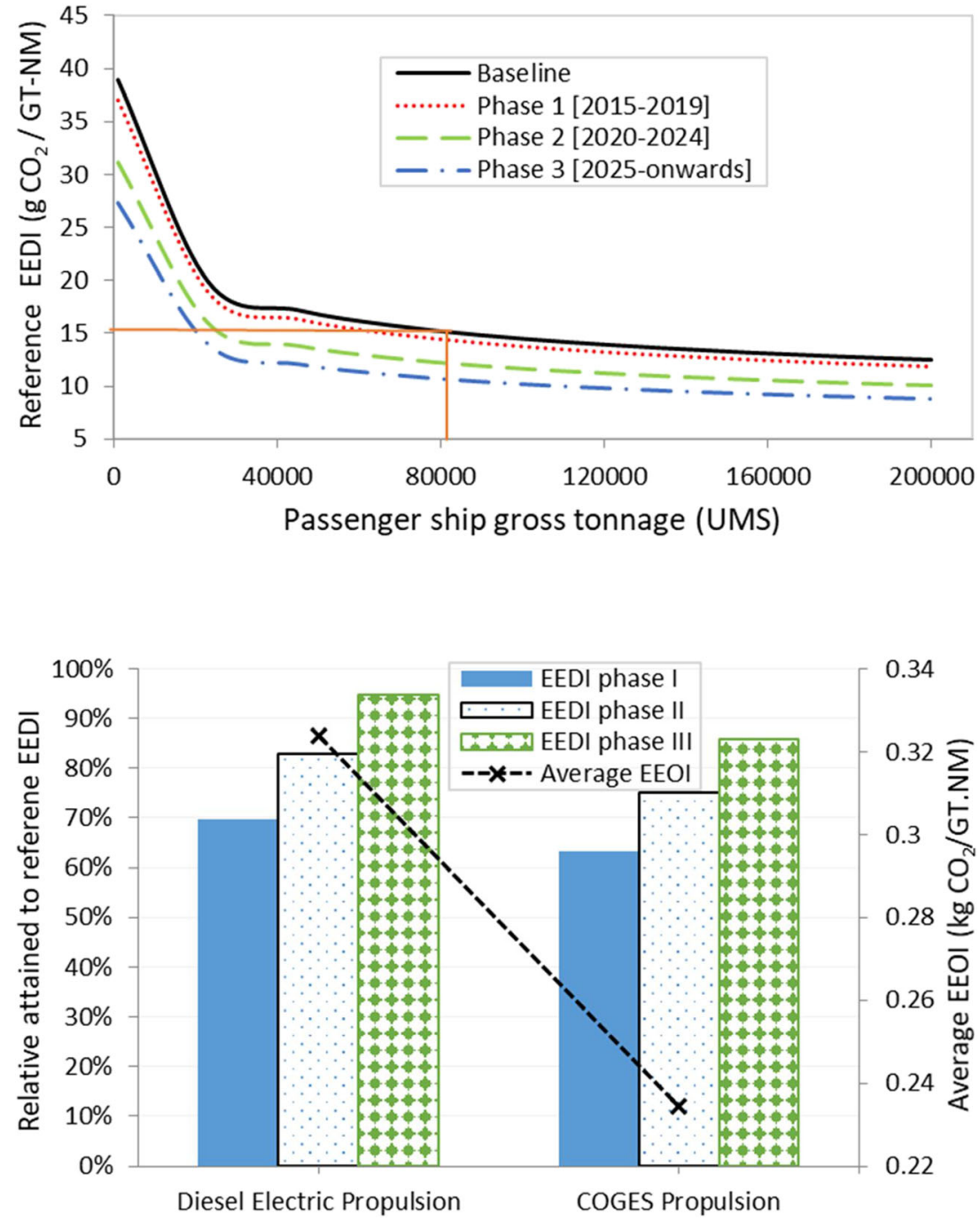

Fig. 11 Relative attained to the reference EEDI and the average EEOI values for the case study $\mathrm{kg} / \mathrm{min}$, respectively. Figure 8 shows the $\mathrm{NO}_{\mathrm{x}}$ and $\mathrm{SO}_{\mathrm{x}}$ emission rates from $\mathrm{DE}$ and COGES propulsion options compared with IMO 2016 Tier III and IMO 2020 limits, respectively. Both propulsion systems complied with $\mathrm{IMO} \mathrm{SO}_{\mathrm{x}}$ limits because of the used ultra-low sulfur fuel contents $(0.1 \% \mathrm{~S})$. On
Fig. 12 Equivalent annual costs for DE and COGES electric propulsion systems

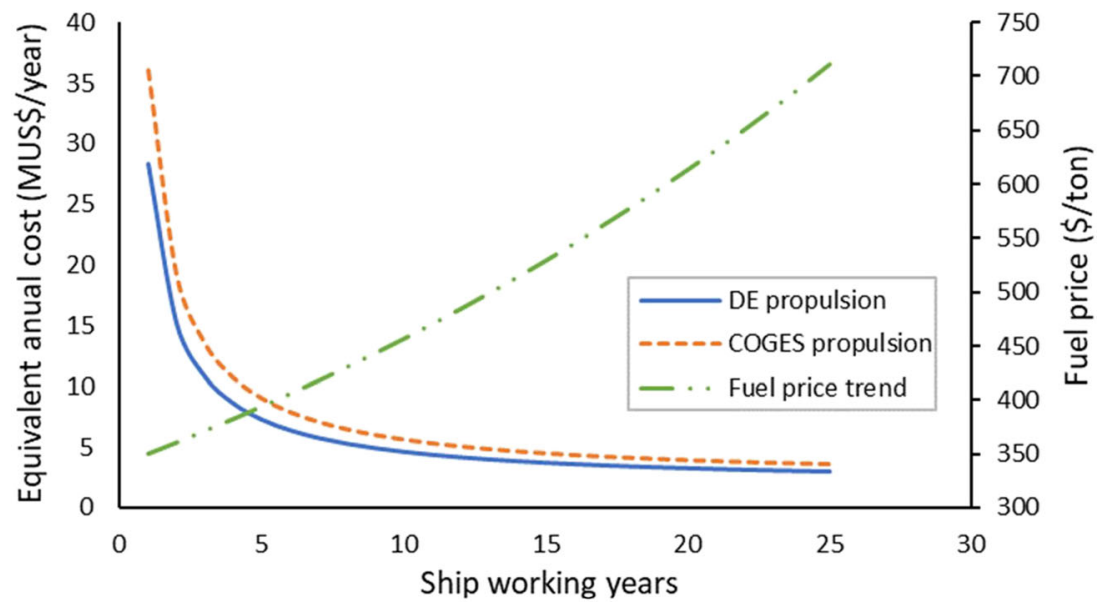


Fig. 13 Life cycle cost per power unit for propulsion options

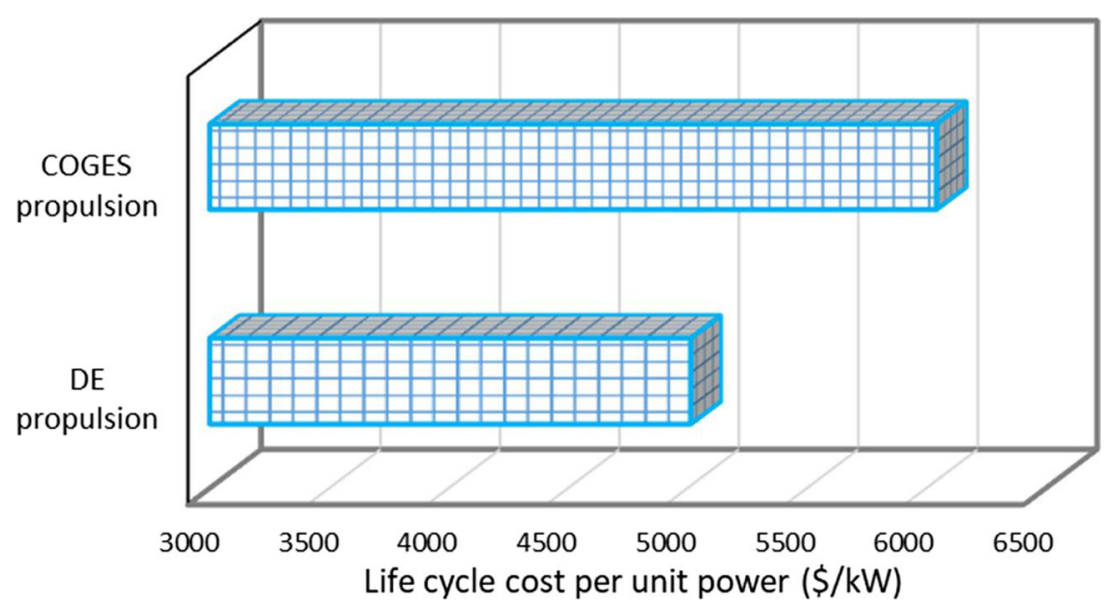

the other hand, the two propulsion options $\mathrm{NO}_{\mathrm{x}}$ emission rates are higher than those of the accepted IMO rates. This is due to the used ULSHFO and MDO $(0.1 \% \mathrm{~S})$ for DE and COGES propulsion options, respectively. Both fuels produce higher $\mathrm{NO}_{\mathrm{x}}$ emission rates than IMO accepted limits. One of the most common after treatment systems for reducing $\mathrm{NO}_{\mathrm{x}}$ emissions is the selective catalytic reduction (SCR) technique.

In order to comply with IMO $\mathrm{NO}_{\mathrm{x}}$ limits, SCR system is proposed to be installed in the exhaust gas system for both $\mathrm{DE}$ and COGES propulsion options. SCR system can reduce $\mathrm{NO}_{\mathrm{x}}$ emissions by up to $90 \%$ (Ammar and Seddiek 2020b; Ammar and Seddiek 2020a). The operation of SCR system depends mainly on urea mixing, reactor temperature, and the performance of the used soot blowers. The system uses urea as a reducing agent. $\mathrm{NO}_{\mathrm{x}}$ reduction is achieved within a catalyst system. The catalysts are typically made of vanadium pentoxide $\left(\mathrm{V}_{2} \mathrm{O}_{5}\right)$ /tungsten trioxide $\left(\mathrm{WO}_{3}\right)$ maintained on titanium dioxide $\left(\mathrm{TiO}_{2}\right)$. Nitric oxide is reduced by the $\mathrm{NH}_{3}$ injected in the SCR catalyst bed at high temperatures above $300^{\circ} \mathrm{C}$ (Monterroso et al. 2011; Romero and Wang 2019; Miller 2011). The efficiency of the SCR system decreases at low engine loads compared with its efficiency at maximum continuous rates. The correct operation of SCR system should include 30- to 40-min warming for the reactor in order to make sure that the catalyst surface is clean (Christensen 2018). Figure 9 shows the reduction of $\mathrm{NO}_{\mathrm{x}}$ emissions at various engine loads compared with IMO 2016 Tier III limits. It is noted that COGES and DE propulsion options are complied with IMO limits after using SCR system.

On the other hand, the IMO reference values for $\mathrm{CO}_{2}$ emissions for passenger vessels can be calculated using MARPOL convention under annex VI. These values are based on the gross tonnage of the passenger vessel and the reduction ratios in three phases. Figure 10 shows the reference EEDI values for the passenger vessels expressed in $\mathrm{gCO}_{2} / \mathrm{GT}-\mathrm{NM}$. The baseline value for the case study vessel with 82,897 gross tonnage is $15.14 \mathrm{gCO}_{2} / \mathrm{GT}-\mathrm{NM}$. This value is reduced to be $14.38,12.11$, and $10.6 \mathrm{gCO}_{2} / \mathrm{GT}-\mathrm{NM}$ with reduction percentages of 5\%,20\%, and $30 \%$ for the first, the second, and the third phases, respectively.

The case study actual values for the EEDI are calculated using attained EEDI at ship speed of 22 knots and 82,897 gross tonnage. Regarding the $\mathrm{CO}_{2}$ emission calculations, the carbon conversion factor of the used fuels plays a role and its
Fig. 14 Life cycle cost elements for DE and COGES propulsion systems

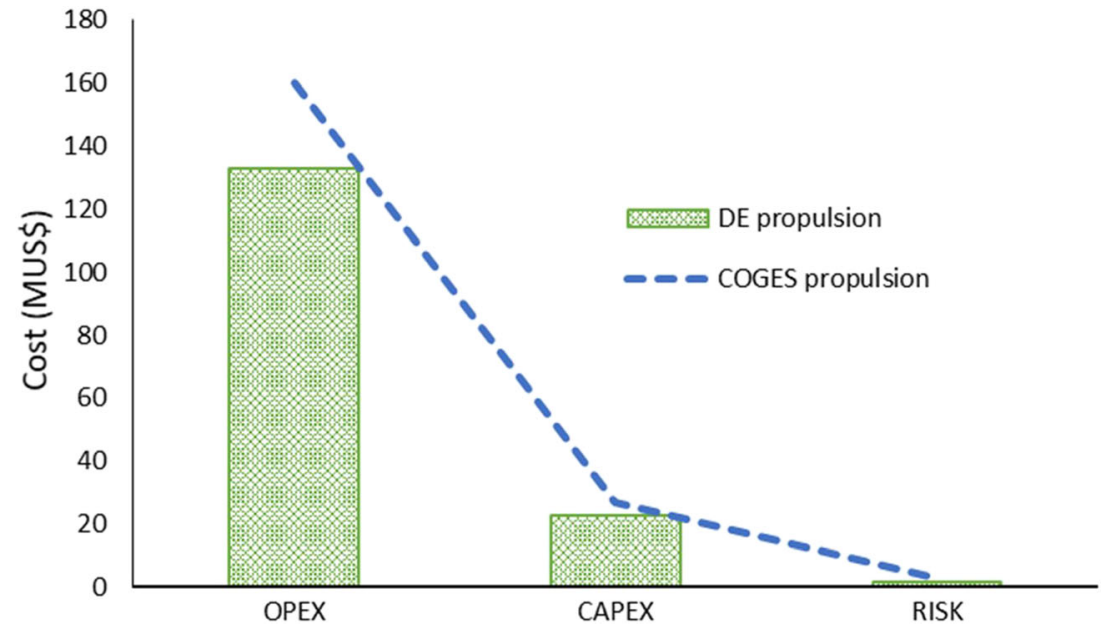




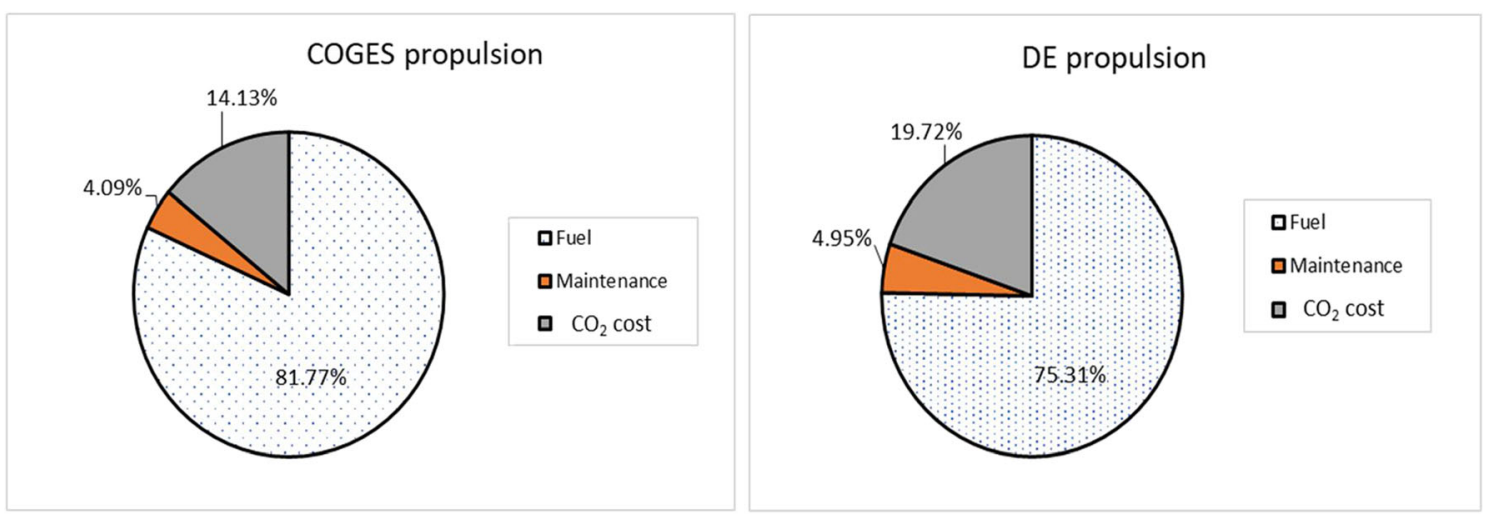

Fig. 15 Contribution percentage of OPEX elements for DE and COGES systems

values are 3.114 and $3.206 \mathrm{t}-\mathrm{CO}_{2} / \mathrm{t}$-fuel, for $\mathrm{DE}$ and COGES propulsions respectively. From the operational point of view, the average EEOI is calculated for the ship route. Figure 11 shows the relative attained to the reference EEDI values and the average EEOI for the case study selected DE and COGES propulsion options. It can be noted that both systems achieve the required EEDI values, with higher EEOI values for the DE propulsion system. The percentages for the relative attained to the reference EEDI values are $94.6 \%$ and $85.8 \%$ for DE and COGES propulsion options, respectively. The average EEOI values are 0.32 and $0.23 \mathrm{~kg} \mathrm{CO}_{2} / \mathrm{GT}$-NM based on average trip distance of 10,560 nautical miles for the case study operated with DE and COGES propulsion options, respectively.

\section{Economic comparison}

Given that obtaining results related to ship economics is a very complex process due to its being affected by many factors that are difficult to determine with high accuracy, the research adopted its methodology, with regard to the economic aspect of propulsion systems, in addition to estimated life cycle cost (LCC) values and the equivalent annual cost (EAC). EAC presents the value that determines the annual cost of the propulsion system as one of the economic measures that can depend on it. Moreover, based on the power rating, sailing time, ship's age, and different elements of ship's life cycle for each propulsion system, the values of life cycle cost for both diesel and COGES systems are estimated. For calculation, the following parameters are taken into consideration: the unit costs of installing power plant are 400 and 560 USD for both diesel and COGES systems, respectively (Pauschert 2009; Altosole et al. 2017; Haglind 2008; EIA 2017); the interest rate is $10 \%$ (Banawan et al. 2010); fuel prices are 350 and 510 USD per ton for ULSHFO and MDO, respectively (Bunkerworld 2020). Due to the complexity of the cost elements of the economic study, there are some elements, such as maintenance and $\mathrm{CO}_{2}$ tax costs, that were assumed to be fixed during the ship life cycle period due to the lack of real expected values and to facilitate the calculations. The maintenance cost is assumed to a rate of $5.2 \mathrm{USD} /$ $\mathrm{kW}$ (Altosole et al. 2017). The cost of $\mathrm{CO}_{2}$ tax is assumed $32 \$ /$ ton (Ahn et al. 2017). By referring to the data on the ship subject to this search, the values of EAC are 2.72 and 3.29 million USD per year, for both diesel and COGES electric propulsion system, respectively, as shown Fig. 12. This reveals that the annual cost of DE option is less than that of COGES by $20.9 \%$.

Depending on the collected data related to operation and maintenance activities of each propulsion system, the values of
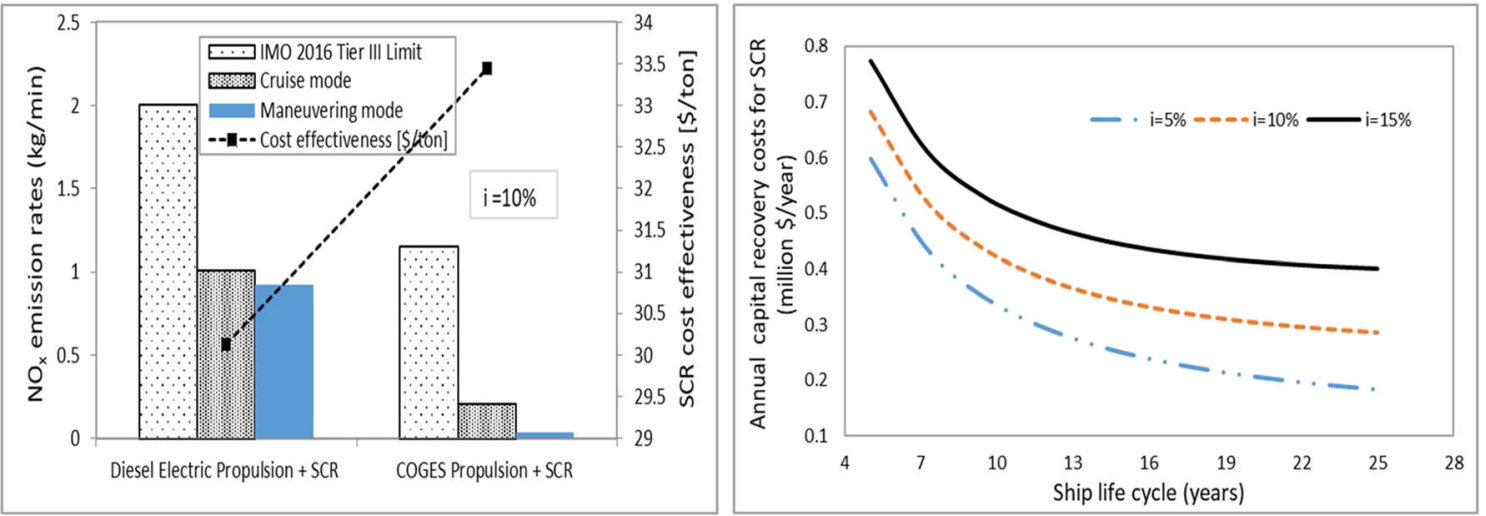

Fig. $16 \mathrm{SCR} \mathrm{NO}_{\mathrm{x}}$ emission-reduction cost-effectiveness and its annual costs 
Fig. 17 Emission-reduction life cycle cost-effectiveness

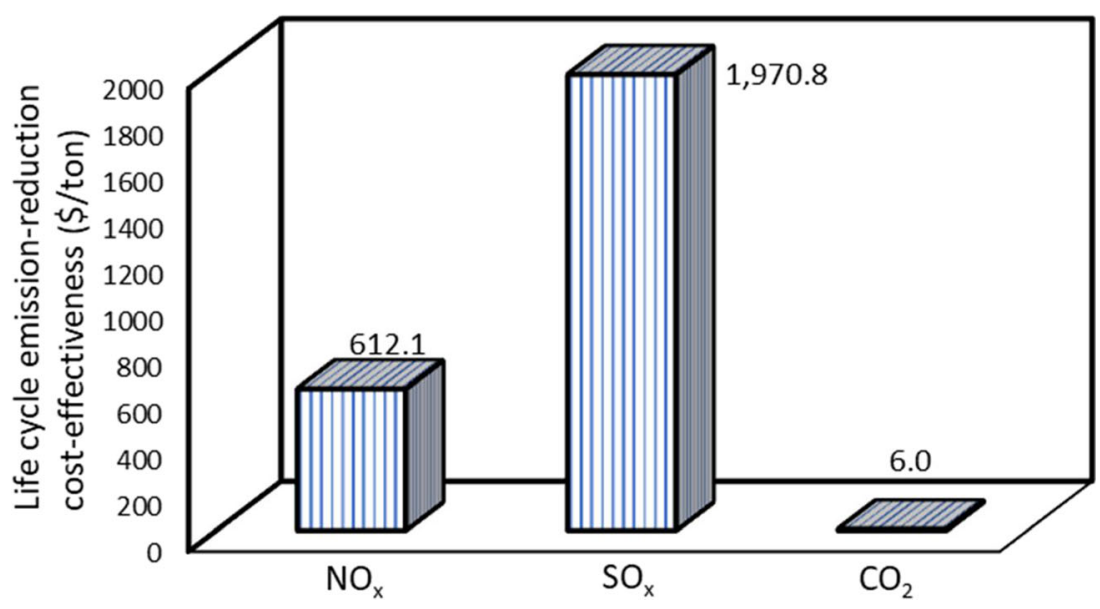

LCC are estimated to be 251.902 and 278.788 million dollars for DE and COGES propulsion system, respectively. Moreover, the values of life cycle per power unit are 5,013 and $6,042 \$ / \mathrm{kW}$ for both diesel and COGES electric propulsion system, respectively, as shown in Fig. 13. From the figure, it is noticed that the value of LCC per kilowatt for diesel electric system is less than the same specification of COGES electric propulsion system by $9.34 \%$. The previous results disclose that using diesel engines as a prime mover for electric propulsion passenger ships will be more effective from the point view of economic side.

Figure 14 presents the LCC components in million dollars for DE and COGES systems. The figure shows that the OPEX, CAPEX, and RISK percentages are $14.2 \%, 84.3 \%$, and $1 \%$ for DE system and $84.0 \%, 14.5 \%$, and $1.5 \%$ for COGES system of the total LCC. It can be said that both CAPEX and OPEX play an effective role in determining the extent of the possibility of implementing the selected system.

Figure 15 shows the contribution of OPEXs elements in MUS\$. It can be noticed that DE system fuel cost presents the highest value, and the maintenance cost is the lowest value with $75.31 \%$ and $4.95 \%$ of the total OPEXs cost, respectively. On the other hand, for COGES system, the fuel cost has the highest sharing value by $81.77 \%$ followed by the $\mathrm{CO}_{2}$ cost of $14.14 \%$ and the maintenance cost of $4.1 \%$.

The previous results prove that COGES is an environmental option for passenger ships; however, it is more costly than DE system propulsion engines which appear more economical. Therefore, a cost-effectiveness study is necessary to evaluate the different propulsion options. Figure 16 shows the annual cost-effectiveness for reducing $\mathrm{NO}_{\mathrm{x}}$ emissions using SCR system and the annual cost for capital cost recovery over ship life cycle. The initial capital costs for installing SCR is $50 \$ / \mathrm{kW}$ with an operating and maintenance costs of $0.00375 \$ / \mathrm{kWh}$ and $0.0009 \$ / \mathrm{kWh}$, respectively (Ammar and Seddiek 2020a). The annual costs for using SCR system is very important in the economic evaluation for the selected propulsion option in order to be complied with IMO $\mathrm{NO}_{\mathrm{x}}$ emission regulations. The annual capital recovery costs for using SCR system are $0.183,0.285$, and 0.40 million dollars/year at the end of the ship life cycle, assuming annual interest rates of $5 \%, 10 \%$, and $15 \%$, respectively. Finally, the annual $\mathrm{NO}_{\mathrm{x}}$ emission-reduction cost-effectiveness values for SCR system are 30.13 and $33.44 \$$ ton with annual emission reductions by 28,860 and 25,866 ton/year for DE and COGES propulsion options, respectively.

However, for a long run, the value of emission-reduction life cycle cost-effectiveness (ELCCE) could be used as a measure with regard to this point. Figure 17 presents those values for the most effective ship's emissions.

It can be remarked that there is a possibility of using COGES propulsion system with emissions life cycle costeffectiveness of 612,1970 , and $6 \$$ per ton emission reduction of $\mathrm{NO}_{\mathrm{x}}, \mathrm{SO}_{\mathrm{x}}$, and $\mathrm{CO}_{2}$ emissions, respectively. Although this may seem costly, it is considered to be a step on the right way to get green ships and reduce the risks that may affect human beings, especially in the ports where the passenger ships' visits are close to the residential areas.

In addition to the abovementioned results, the limitations of the COGES plant for passenger ships, apart from the economic reason, include the following points. The main problems of COGES system are its complexity, the large machinery space required, and waste heat recovery arrangement systems (MAN B\&W 2015; Allevi and Collodi 2017).

\section{Conclusions}

Two electric propulsion options are investigated for a passenger ship. A comparison between diesel electric (DE) and combined gas turbine electric and steam (COGES) propulsion systems is presented from the environmental and economic points of view. The main conclusions from the current study are as follows:

- From the environmental point of view, DE and COGES propulsion options operated by ULSHFO and MDO $(0.1 \% \mathrm{~S})$ comply with IMO $\mathrm{SO}_{\mathrm{x}}$ and $\mathrm{NO}_{\mathrm{x}}$ emission limits after 
installing selective catalytic reduction system (SCR) onboard. COGES propulsion option shows better environmental benefits than $\mathrm{DE}$ system. It produces less $\mathrm{NO}_{\mathrm{x}}$ emission rates by $8.81 \%$ and negligible $\mathrm{SO}_{\mathrm{x}}$ emissions. In addition, both the energy efficiency design index and the operational indicator are improved using COGES propulsion system by $9.3 \%$ and $27.55 \%$, respectively, compared with DE system.

- From the economic point view, the values of equivalent annual costs are 2.72 and 3.29 M\$, for both DE and COGES propulsion systems, respectively. The values of the life cycle costs per unit power are 5,013 and $6,042 \$ / \mathrm{kW}$ with total life cycle costs of 251.902 and 278.788 MUS\$, respectively. The OPEXs, CAPEXs, and RISK percentages are $14.2 \%, 84.3 \%$, and $1 \%$ for DE system and $84.0 \%, 14.5 \%$, and $1.5 \%$ for COGES system of the total life cycle costs.

- To sum up, COGES propulsion system can be proposed as an upgrade option for ships that use gas turbines as their main propulsion. It appears as a greener propulsion option with extra cost more than DE system by $20.9 \%$. COGES propulsion system can be used for the selected passenger ship with life-cycle cost-effectiveness of 612, 1970, and $6 \$ /$ ton for $\mathrm{NO}_{\mathrm{x}}, \mathrm{SO}_{\mathrm{x}}$, and $\mathrm{CO}_{2}$ emissions, respectively.

Abbreviations CAPEX, Capital expenditures; COGES, Combined gas turbine electric and steam; $\mathrm{CO}_{2}$, Carbon dioxide emissions; DE, Diesel electric propulsion; EEDI, Energy efficiency design index; EEOI, Energy efficiency operational indicator; HV, High voltage; IMO, International Maritime Organization; LCC, Life cycle cost; MDO, Marine diesel oil; $\mathrm{NO}_{\mathrm{x}}$, Nitrogen oxide emissions; OPEX, Operating expenditures; RISKEX, Risk expenditures; S, Sulfur; SCR, Selective catalytic reduction; $\mathrm{SO}_{\mathrm{x}}$, Sulfur oxide emissions; ULSFO, Ultra-low sulfur fuel oil

Author contribution Nader R. Ammar: conceptualization, methodology, software, visualization, investigation, writing - reviewing and editing. Ibrahim S. Seddiek: data curation; writing - original draft preparation; methodology; visualization; investigation; writing — reviewing and editing.

Data Availability Data sharing is not applicable to this article as no datasets were generated or analyzed during the current study.

\section{Declarations}

Ethical approval Not applicable

Consent to participate Not applicable

Consent to publish Not applicable

Competing interests The authors declare no competing interests.

\section{References}

ABS (2013) Ship energy efficiency measures: status and guidance. American Bureau of Shipping, Houston
Acomi N, Acomi OC (2014) Improving the voyage energy efficiency by using EEOI. Procedia Soc Behav Sci 138:531-536

Ahn J, You H, Ryu J, Chang D (2017) Strategy for selecting an optimal propulsion system of a liquefied hydrogen tanker. Int J Hydrog Energy 42:5366-5380. https://doi.org/10.1016/j.ijhydene.2017.01. 037

Allevi C, Collodi G (2017) 21 - Case study: Sarlux IGCC power plant, Italy. In: Wang T, Stiegel G (eds) Integrated gasification combined cycle (IGCC) technologies. Woodhead Publishing

Altosole M, Benvenuto G, Campora U, Laviola M, Trucco A (2017) Waste heat recovery from marine gas turbines and diesel engines. Energies 10(5):1-24

Ammar NR (2019) Environmental and cost-effectiveness comparison of dual fuel propulsion options for emissions reduction onboard LNG carriers. Brodogradnja/Shipbuilding 70(3):61-77

Ammar NR, Seddiek IS (2017) Eco-environmental analysis of ship emission control methods: case study RO-RO cargo vessel. Ocean Eng 137:166-173

Ammar NR, Seddiek IS (2018) Thermodynamic, environmental and economic analysis of absorption air conditioning unit for emissions reduction onboard passenger ships. Transp Res Part D: Transp Environ 62:726-738

Ammar NR, Seddiek IS (2020a) Enhancing energy efficiency for new generations of containerized shipping. Ocean Eng 215:107887

Ammar NR, Seddiek IS (2020b) An environmental and economic analysis of emission reduction strategies for container ships with emphasis on the improved energy efficiency indexes. Environ Sci Pollut Res 27:23342-23355

Banawan AA, EL Gohary MM, Sadek IS (2010) Environmental and economical benefits of changing from marine diesel oil to naturalgas fuel for short-voyage high-power passenger ships. Proc Inst Mech Eng Part M-J Eng Mar Environ 224:103-113

Bassam AM, Phillips AB, Turnock SR, Wilson PA (2016) An improved energy management strategy for a hybrid fuel cell/battery passenger vessel. Int J Hydrog Energy 41:22453-22464

Bassam AM, Phillips AB, Turnock SR, Wilson PA (2017) Development of a multi-scheme energy management strategy for a hybrid fuel cell driven passenger ship. Int J Hydrog Energy 42:623-635

Benvenuto G, Bertetta D, Carollo F, Campora U (2011) COGAS plant as possible future alternative to the diesel engine for the propulsion of large ships. In: Sustain Mar Transp Exploitation Sea Resources Rizzuto \& Guedes Soares

Benvenuto G, Bertetta D, Carollo F, Campora U (2012) In: Sustainable Maritime Transportation and Exploitation of Sea Resources Rizzuto \& Guedes Soares (ed) COGAS plant as possible future alternative to the diesel engine for the propulsion of large ships, vol 978-0-415-62081-9. Taylor \& Francis Group, London, pp 603-613

BUNKERWORLD (2020) Bunkerworld. Fuel prices. Available: http:// www.bunkerworld.com/prices/ [Online]. Accessed 29 October 2020

Capasso C, Notti E, Veneri O (2019) Design of a hybrid propulsion architecture for midsize boats. Energy Procedia 158:2954-2959

CAT (2012) Diesel generator $4000 \mathrm{ekW}, 5000 \mathrm{kVA}, 60 \mathrm{~Hz}$, and $900 \mathrm{rpm}$ [Online]. Available: https://s7d2.scene7.com/is/content/Caterpillar/ CM20170906-16192-28043. Accessed 22 October 2020

Christensen SR (2018) Selective catalytic reduction of NOx on ships. Ph.D. thesis, Technical University of Denmark.

Clarksons Research (2020) Reearch's world fleet register [Online]. Available: https://clarksonsresearch.wordpress.com/2017/03/31/ setting-a-course-towards-a-cleaner-future/ [Accessed 23 October 2020].

CRUISEMAPPER (2020) Specifications of ms Noordam [Online]. Available: https://www.cruisemapper.com/ships/ms-Noordam-613. Accessed 20 October 2020 
Curley R (2012) The complete history of ships and boats. Britannica Educational Publishing, New York

Dedes EK, Hudson DA, Turnock SR (2012) Assessing the potential of hybrid energy technology to reduce exhaust emissions from global shipping. Energy Policy 40:204-218

Doumbia-Henry C (2020) Shipping and COVID-19: protecting seafarers as frontline workers. WMU J Mar Aff 19(279-293):1-15

EIA (2017) Construction costs for most power plant types have fallen in recent years [Online]. Available: https://www.eia.gov/ todayinenergy/detail.php?id=31912. Accessed 29 October 2020

Elgohary MM, Seddiek IS, Salem AM (2014) Overview of alternative fuels with emphasis on the potential of liquefied natural gas as future marine fuel. Proc Inst Mech Eng Part M: Journal of Engineering for the Maritime Environment 229:365-375

EUROPEAN COMMISSION (2014) Guide to cost-benefit analysis of investment projects economic appraisal tool for Cohesion Policy 2014-2020, Technical report. Belgium. ISBN 978-92-79-34796-2$10.2776 / 97516$

Geertsma RD, Negenborn RR, Visser K, Hopman JJ (2017) Design and control of hybrid power and propulsion systems for smart ships: A review of developments. Appl Energy 194:30-54

General Electric (2019) LM2500 power plants $(60 \mathrm{~Hz})$ [Online]. Available: https:/www.ge.com/content/dam/gepower/global/en US/documents/gas/gas-turbines/aero-products-specs/lm2500-60hzfact-sheet-product-specifications.pdf. Accessed 21 October 2020

GL (2013) Guidelines for determination of the energy efficiency design index [Online]. Available: http://rules.dnvgl.com/docs/pdf/gl/ maritimerules2016July/gl vi-13-1 e.pdf. Accessed 3 April 2020

Haglind F (2008) A review on the use of gas and steam turbine combined cycles as prime movers for large ships. Part II: previous work and implications. Energy Convers Manag 49:3468-3475

Halff A, Younes L, Boersma T (2019) The likely implications of the new IMO standards on the shipping industry. Energy Policy 126:277286

Holland America Line (2020) Cruise line and voyages [Online]. Available: https://www.hollandamerica.com/en US.html. Accessed 22 October 2020

Hong JT, Kang KH, Bae JC (2012) Establishment of evaluation infrastructure for research and certification of electric propulsion vessels. Bull Soc Naval Archit Korea 49:60-65

IACS (2016) Procedure for calculation and verification of the Energy Efficiency Design Index (EEDI) [Online]. Available: http://www. iacs.org.uk/download/5816. Accessed 20 October 2020

Ibrahim TK, Rahman MM, Abdalla AN (2011) Gas turbine configuration for improving the performance of combined cycle power plant. Proc Eng 15:4216-4223

IMO (2014) Resolution MEPC 245(66): 2014 guidelines on the method of calculation of the attained Energy Efficiency Design Index (EEDI) for new ships. MEPC 66/21/Add.1, Annex 5, 4 April 2014. International Maritime Organization, London

IMO (2020) Reduction of GHG emissions from ships. Fourth IMO GHG Study 2020 - Final report. In: MEPC 75/7/15

Jaurola M, Hedin A, Tikkanen S, Huhtala K (2019) Optimising design and power management in energy-efficient marine vessel power systems: a literature review. J Marit EngTechnol 18:92-101

Jeon H, Kim J (2020) Application of reference voltage control method of the generator using a neural network in variable speed synchronous generation system of DC distribution for ships. J Mar Sci Eng 8:802

Jeong B, Oguz E, Wang H, Zhou P (2018) Multi-criteria decision-making for marine propulsion: hybrid, diesel electric and diesel mechanical systems from cost-environment-risk perspectives. Appl Energy 230: 1065-1081

Kim SY (2007) Suppression of the thrust loss for the maximum thrust operation in the electric propulsion ship. Master's thesis. Seoul National University
Kim YM (2013) Power management system modeling and characteristics analysis for electric propulsion ship. Master's thesis. Sungkyunkwan University

Koo DH (2009) Electric propulsion ship technology trend. Korean Inst Electr Eng World of Electr 58:36-43

Kwak KK (2014) A study on integrated-power-system simulation model of electric-propulsion-ship. Pusan National University, Master's thesis

Lee DK, Jeong Y-K, Shin JG, Oh D-K (2014) Optimized design of electric propulsion system for small crafts using the differential evolution algorithm. Int J Precis Eng Manuf-Green Technol 1:229-240

Lee PT-W (2019) Sustainability challenges in maritime transport and logistics industry and its way ahead. Sustainability 11:5

Lim C-O, Park B-C, Lee J-C, Kim ES, Shin S-C (2019) Electric power consumption predictive modeling of an electric propulsion ship considering the marine environment. Int J Naval Archit Ocean Eng 11: 765-781

Magdalena K, Wojciech L (2019) Energy efficient small inland passenger shuttle ferry with hybrid propulsion - concept design, calculations and model tests. Polish Marit Res 26:85-92

MAN (2018) Diesel-electric drives [Online]. Available: https://marine. mandieselturbo.com/docs/librariesprovider6/marine-broschures/ diesel-electric-drives-guideline.pdf. Accessed 22 October 2020

Man B\&W (2015) Soot deposits and fires in exhaust gas boiler [Online]. Available: http://www.dieselduck.info/machine/06\%20safety/ MAN\%20B\&W\%20Soot\%20in\%20EGBs.pdf. Accessed 2 February 2021

Marine Traffic (2020) Oosterdam passenger vessel information [Online] Available: https://www.marinetraffic.com/en/ais/details/ships/ shipid:260088/mmsi:245417000/imo:9221281/vessel: OOSTERDAM. Accessed 22 October 2020

Michail NA, Melas KD (2020) Shipping markets in turmoil: an analysis of the Covid-19 outbreak and its implications. Transportation 7: 100178

Miller BG (2011) 9-Emissions control strategies for power plants. In: Miller BG (ed) Clean Coal Engineering Technology. ButterworthHeinemann, Boston

Mohseni SA, VAN Hassel E, Sys C, Vanelslander T (2019) Economic evaluation of alternative technologies to mitigate sulphur emissions in maritime container transport from both the vessel owner and shipper perspective. J Shipp Trade 4:15

Monterroso R, Fan M, Argyle M (2011) Chapter 9 - mercury removal. In: Bell DA, Towler BF, Fan M (eds) Coal gasification and its applications. William Andrew Publishing, Boston

Mrzljak V, Mrakovčić T (2016) Comparison of COGES and diesel-electric ship propulsion systems. J Marit Transp Sci Special edition: $131-148$

Nuchturee C, Li T, Xia H (2020) Energy efficiency of integrated electric propulsion for ships - a review. Renew Sust Energ Rev 134:110145

Olmer N, Comer B, Roy B, Mao X, Rutherford D (2017) Greenhouse gas emissions from global shipping [Online]. Available: https:/theicct. org/publications/GHG-emissions-global-shipping-2013-2015. Accessed 29 October 2020

Ouyang T, Zhao Z, Lu J, Su Z, Li J, Huang H (2020) Waste heat cascade utilisation of solid oxide fuel cell for marine applications. J Clean Prod 275:124133

Pauschert D (2009) Study of equipment prices in the power sector. In: Energy sector management assistance program. ESMAP Technical Paper 122/09, Washington

Peng H, Zhu X, Yang L, Zhang G (2020) Robust controller design for marine electric propulsion system over controller area network. Control Eng Pract 101:104512

Prempraneerach P, Kirtley J, Chryssostomidis C, Triantafyllou MS, Karniadakis GE (2009) Design of the all-electric ship: focus on integrated power system coupled to hydrodynamics. In: Proceedings of the American Society of Naval Engineers and the 
Society of Naval Architects and Marine Engineers Electric Ship Design Symposium, February 2009

Rivera-Alvarez A, Coleman MJ, Ordonez JC (2015) Ship weight reduction and efficiency enhancement through combined power cycles. Energy 93:521-533

Romero CE, Wang X (2019) Chapter three - key technologies for ultralow emissions from coal-fired power plants. In: Zhang Y, Wang T, Pan W-P, Romero CE (eds) Advances in ultra-low emission control technologies for coal-fired power plants. Woodhead Publishing

Ros Chaos S, Pallis AA, Saurí Marchán S, Pino Roca D, Sánchez-Arcilla Conejo A (2020) Economies of scale in cruise shipping. Mar Econ Logist

Sadek I, Elgohary M (2020) Assessment of renewable energy supply for green ports with a case study. Environ Sci Pollut Res 27:5547-5558

Seddiek IS (2016) Two-step strategies towards fuel saving and emissions reduction onboard ships. Ships Offshore Struct 11:791-801

Su Z, Ouyang T, Chen J, Xu P, Tan J, Chen N, Huang H (2020) Green and efficient configuration of integrated waste heat and cold energy recovery for marine natural gas/diesel dual-fuel engine. Energy Convers Manag 209:112650

Szymon G (2018) Alternative propulsion plants for modern LNG carriers. New Trends Prod Engi 1:399-407
UNCTAD (2019) Review of maritime transport 2019. United Nations Conference On Trade and Development [Online]. Available: https://unctad.org/en/PublicationsLibrary/rmt2019_en.pdf. Accessed 20 August 2020

WARTSILA (2020) Wartsila energy solutions [Online]. Available: https://www.wartsila.com/docs/default-source/power-plantsdocuments/pps-catalogue.pdf. Accessed 22 October 2020

Welaya YMA, Mosleh M, Ammar NR (2014) Thermodynamic analysis of a combined solid oxide fuel cell with a steam turbine power plant for marine applications. Brodogradnja 65:97-116

Xiao N, Xu X, Chen B (2020) Research on simulation and experiment of ship complex diesel-electric hybrid propulsion system. J Ship Res 64:171-184

Zahedi B, Norum LE (2013) Modeling and simulation of all-electric ships with low-voltage DC hybrid power systems. IEEE Trans Power Electron 28:4525-4537

Publisher's note Springer Nature remains neutral with regard to jurisdictional claims in published maps and institutional affiliations. 